\title{
Construction and application of micro course in college English teaching model --With audio-visual course as an example
}

\author{
Xia Wang ${ }^{1, a}$ \\ ${ }^{1}$ Foreign Language Teaching and Research Department, Jilin University of Finance and Economics, \\ China \\ a87696682@qq.com
}

Keywords: Micro course, College English, English teaching, audio-visual

\begin{abstract}
In recent years, with the rapid development of English education, English education reform in full swing. Shoulders and cultivate new type of professional and technical personnel specialized English of ability in English teaching want to be able to improve the traditional teaching mode. At the same time, with the development of information technology, the present China is entering an era of micro: Weibo, WeChat, micro film, tiny said... The micro course also quietly appeared. Therefore, "micro course" is a new way of teaching, is increasingly deep into our daily life and teaching activities.
\end{abstract}

\section{Introduction}

At present, the ministry of education also in class actively promoting micro this kind of new teaching methods. The ministry of education of the two units are actively promoting micro class competition [1]. One is the education management information center and north of anonymous group cooperation, micro class competition for primary and secondary school teachers. Another is the ministry of education's nationwide network of university teachers' training center organization of micro teaching competition first national colleges and universities [1]. In addition to the push of ministry of education, in many provinces, municipalities, autonomous regions and their subordinate administrative department of education, is also actively promote the design, development and application of micro class. In this context, the small class and English teaching organically, will help to improve the students' learning interest and learning effect, to strengthen the professional English application ability and the ability of students, so that the students can meet the needs of future jobs.

\section{Micro course introduction}

The concept of micro class. Video lesson "micro" refers to teaching as the main carrier, record teachers around certain knowledge or teaching conduct short, complete the teaching activities. Or, the class is a short video, present a single, strict definition of the Lord. It with a certain knowledge point as the goal, in a short online video for forms, for the purpose of learning or teaching application.

"Class" is the core content of classroom teaching video, but related to the teaching topic teaching design, teaching courseware, exercise test, teaching reflection, teachers' comments, and feedback teaching support resources are also included [2]. "Small class", therefore, different from the traditional single teaching resource type, but on the basis of the inheritance and development of a new type of teaching resources, shown as Fig.1.

The characteristics of the micro class. The so-called "class", first performance in its short - the video is generally in about 10 minutes. Of course, its teaching content is relatively small. In a short time, based on the school resources, the ability of the teachers and students interest, micro class formed a relatively independent and complete small courses [2]. It change numerous for brief, short, only to learn the core content, not learn, just learn need most, only to learn the most useful. It is a simplified, subdivision of the teaching process, students and therefore easy to master. 


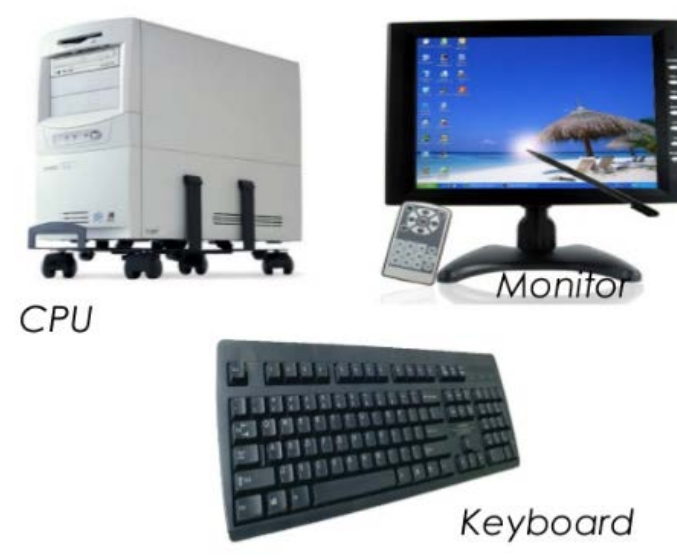

Fig.1 The use of micro class equipment

"Micro Class" only around a certain knowledge or teaching link to carry out teaching activities, thus the teaching goal clear, focused. Relative to the traditional classroom, the teaching activities to more clear and focused. It makes the students and teachers may focus on a specific teaching behavior [2].

"Micro Class" video of classroom teaching as the core, but are not limited to a single video materials [2]. It is a composed of numerous resources three-dimensional, diversified resources package: can include teachers do the teaching design, multimedia teaching courseware, course practice, related testing, teaching evaluation, teaching reflection and multimedia material, etc.

\section{Colleges and universities of professional English teaching}

Students' learning interest is not high. The current college students, common English foundation is weak, many students English ability also remain in the high school level [3]. They don't have a very good learning methods, learning ability and learning habit, therefore, the professional to learn more of all kinds of professional English is very difficult. Students by making it hard to keep up with progress, an obvious school-weary psychology.

Old teacher's professional knowledge.Language is developing, and as a result of new knowledge, new technology emerge in endlessly, professional English knowledge update more quickly [3]. And professional English teachers often due to the limitation of conditions, the level of knowledge update couldn't keep up with the pace of development, not to master the latest, cutting-edge expertise, eventually lead to can not competent for teaching work very well.

Single evaluation way. In the mode of examination, the most colleges still adopts the traditional form of examination paper, the topic is the same, is nothing more than translation terminology, the text sentence, reading comprehension, etc [2]. Can't really reflect the students' learning process, and also unable to comprehensive study of the students' professional English application ability.

Teaching means lag behind. In college English teaching, many colleges have been using multimedia teaching, and in professional English teaching still stay on the blackboard, chalk, big class, teachers lecture on the pattern of a single, old teaching methods, in this way, students have no interest in learning, teachers also have no teaching enthusiasm, in the long run, hard to cultivate students with good learning ability [1].

\section{The application of micro class in English teaching}

In order to be able to change the present situation of English teaching, improve the students' interest in learning, to promote teachers' teaching ability, promoting the fusion of information technology and subject teaching at the same time, in English teaching, the application of micro class can yet be regarded as a kind of beneficial attempt, will produce good results [3]. In English teaching, the "small class" can be applied in classroom teaching, and online autonomous learning, teachers' professional development, etc. 
Micro class can change the teacher's teaching research pattern, improve the efficiency of the teaching research. Micro class will change traditional way of teaching and research, break through the traditional teachers listen to evaluation model, teachers' electronic lesson preparation, classroom teaching and after-school reflection applications will has more pertinence and effectiveness of resources [4]. For example, teachers during the teaching and research from the tutorial can be inspired by each other, some can even directly migrated to their education teaching. Teachers in this real, concrete and typical case is easy to implement teaching in the situations of teaching and learning ideas, skills, style of imitation, migration and promoted, so as to improve the efficiency of the teaching and research, enhance the level of teachers' classroom teaching [4]. Through micro class with the accumulation of resources, sharing and communication, can also improve the teachers' self-confidence and a sense of accomplishment, also can effectively improve teachers' course teaching and the integration of information technology skills, shown as Fig.2.

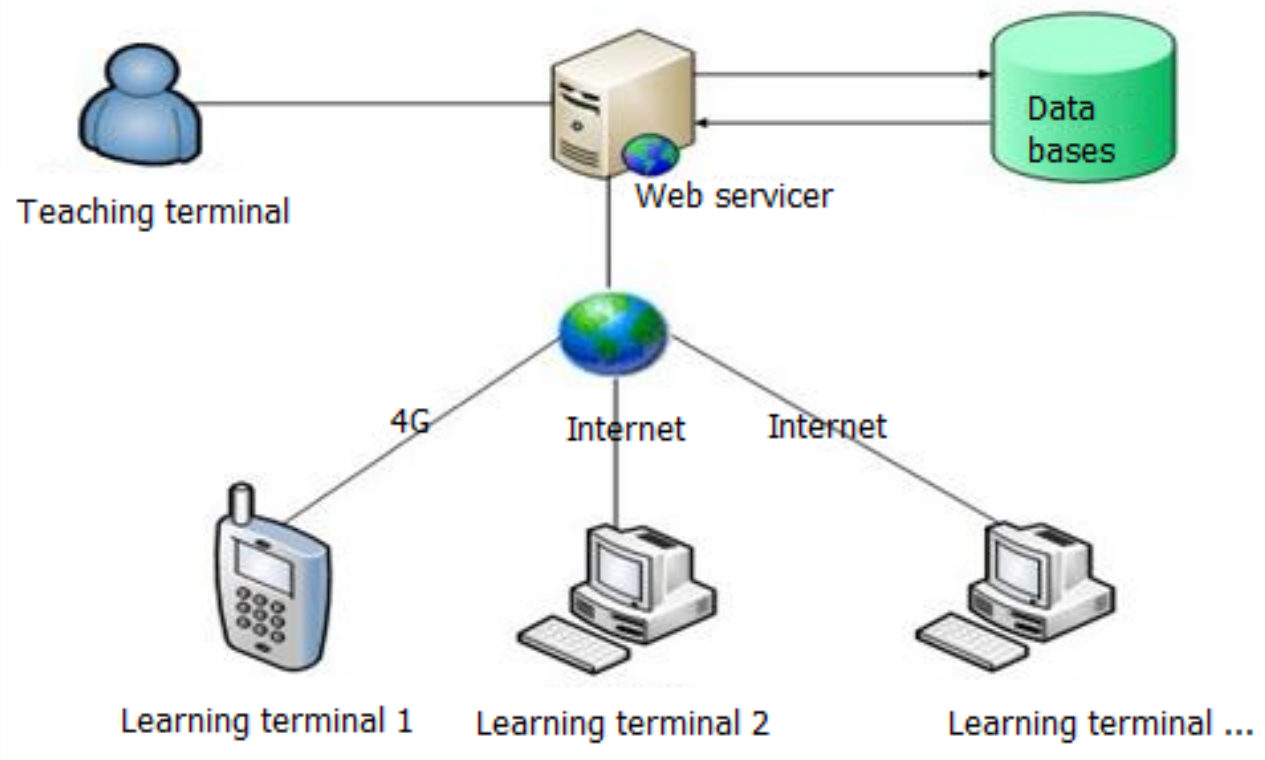

Fig. 2 audio-visual course teaching mode

The classroom teaching. Micro class as a teaching video, the first can be flexible used in classroom teaching, import, the course focuses on the difficulties, used in teaching, after class to expand teaching links [4]. So, due to the emergence of the "class", the boring becomes vivid and many professional English class, students can get more attention.

Review the old lessons. In English teaching, the teacher can according to the teaching requirements, make the old class to review the video, let the students after class to watch, to consolidate what they learned. Whether that many specialized in professional English vocabulary, terminology, and the core content of each unit, can be through the review after class to consolidate.

Import new lesson. Teachers can according to the new theme design, elaborate video as the import material, let the students watch at first class and attract their attention, generate interest in learning. In addition, a lot of thematic unit need to master certain professional knowledge, teachers can make relevant video material, let the students know the related content, thus successfully to enter the learning of this unit

The difficulties in teaching. In the teaching of specialized English, because involves both professional knowledge, and there was a language barrier, there are always some difficult to understand the difficulties of knowledge for students to understand [5]. Fully read the discussion, teachers can help students by watching video, explanation, schemata and list ways to let students have more intuitive understanding of the difficulties of knowledge.

Develop practice. In teaching class, the teacher can set aside some extend to watch video for students after class. These classes can be related reading materials, introduces the relevant professional knowledge and practice test, guides the student to expand knowledge, summarizes the key, practice to improve. 
Independent learning. The rise of micro class because of the micro era. The popularity of the development of modern network and computer made it possible to autonomous learning. American salman khan khan academy mode, reverse influence such as classroom mode, as online video teaching, micro lesson is widely used in online learning [5]. Especially in recent years, the course of design and development is more and more simple and convenient, the application of micro class also increasingly popular. Teacher making micro uploaded to the Internet, students can on demand at any time, at any time to watch, autonomous learning.

The teacher's role change.Teachers are no longer the sole occupant of knowledge and provider, and become the organizers of the classroom and study guide. English description of the change is that the more interesting organizer and guide is not good when: the teacher wants to learning content is very familiar with, and know how online video can provide public class; At the same time, best can know learners' characteristics, personality, cognitive style, learning methods, learning purpose, special experience, etc.)[6]. In other words, the teacher prepares a lesson quantity will not reduce, only revealed a reduction in the class; And ready to must answer the question, will widen the range of thinking, content will be varied, differ in thousands ways. In addition, teachers grasp of the education technology would be taken for granted.

The learner role transformation. Learners become real center: he decided to learn what where and when to learn, how to learn, to learn, learn much, much faster. The learner's initiative to give full play to out [6]: first of all, he is not computer blind, but to mastery network technology. Second, he should take the initiative to understand all the information about the course, including his own responsibility, the responsibility of the teacher, the responsibility of the administrator, etc., to determine their elective professional and curriculum. Third, he must inform within limits in the network, complete course assignments, enough credits, etc as required. Fourth, he have plenty of time and absolute initiative, individual determination and hard work determines his future.

\section{Summary}

Combining micro lessons and classroom teaching, make the teaching process to better carry out exploratory teaching patterns, further play to the role of, among them there are many problems worthy to be discussed. In learning content distribution, for example, how the interpretation of the teachers and students independently explore parts of the division, in the learning process control on how both can allow the individual differences and can guarantee the learning efficiency, on the way for examination and assessment of how to be more accurate, truly reflect the process of evaluation, etc., these problems need further research and practice to answer them.

\section{References}

[1] Zh.L. Liu and J.L. Zhang, Based on the education of information resource integration framework research of cloud, Intelligence Journal, 2013, pp.10-16.

[2] Y.L. Yang, Students facing the globalization, English teaching information technology, the digital age - based on the "Experience English Writing" Research and Training system construction, Foreign language teaching and foreign language students, 2012, vol.05, pp. 20-26.

[3] K.K, He and J.Wu, Information technology and curriculum integration teaching model research, The modern education technology, 2008, vol.9, pp.5-10.

[4] P.F. Wang, Doll's post-modern perspective on curriculum and its enlightenment to our country education, Journal of higher correspondence: philosophy and social sciences, 2002, vol.3, pp.32-36.

[5] T.Sh. Hu, "Micro class": the new trend of development of education information resources, Electrochemical education research, 2011, vol.10, pp.61-65.

[6] G.J. Huang, About the rational thinking of the inquiry-based teaching model and the actual operation, Education theory research, 2005, vol.1, pp.6-11. 